\section{(A) Check for updates}

Cite this: Food Funct., 2018, 9, 1500

\title{
The effects of whey and soy proteins on growth performance, gastrointestinal digestion, and selected physiological responses in rats
}

\author{
B. Wróblewska, (D) J. Juśkiewicz, (D) B. Kroplewski, A. Jurgoński, (iD E. Wasilewska, (DD \\ D. Złotkowska (D) * and L. Markiewicz iD
}

\begin{abstract}
The objective of this work was to identify the nutritional and physiological effects of commercial soy and whey protein preparations. Wistar rats were fed with soy (S), whey (W), or casein (C) preparations as the sole dietary protein source. The nitrogen balance, body composition, changes in caecal microbiota, mucosal and bacterial enzyme activities, and allergenic potential of the preparations were analysed. The whey diet elicited greater skeletal muscle anabolism than the soy diet. Rats from the S group had the lowest values of body weight, fat, and lean mass gain. Compared to casein, soy and whey preparations decreased the protein efficiency ratio, increased $\mathrm{N}$ in the urine, and triggered the reduction of ammonia levels in the caecum. Changes in $\beta$-glucuronidase and $\beta$-galactosidase activities in the small intestine, caecum, and colon between experimental groups were observed. Significant differences were noted in the total counts of anaerobic bacteria and sulphite reducing bacteria during soy and whey treatments. This probably affected the short chain fatty acid level in caecal digesta resulting in the lowest propionic acid and total putrefactive short chain fatty acid levels during S treatment. Generally, whey preparations are a good choice for rapid bodybuilding (skeletal muscles), whereas soy preparations are more helpful during mass reduction.
\end{abstract}

Received 4th August 2017

Accepted 11th January 2018

DOI: $10.1039 / \mathrm{c} 7 f \circ 01204 \mathrm{~g}$

rsc.li/food-function most popular plant proteins utilized in the production of newborn formulas and dietary supplements.

Diet provides nutritional and functional components to the body, which after digestion may reveal diverse properties and result in health consequences beyond the gastrointestinal tract. $^{7}$ A high-protein diet is associated with metabolic disorders, as it affects functioning of the heart, kidneys, and liver, and increases the risk of cardiovascular diseases. ${ }^{8-10}$ Moreover, whey and soy proteins are classified as strong food allergens and may trigger allergies or side effects. ${ }^{11}$

Eating habits, and thus long-term supply of particular diet components (proteins or carbohydrates) shape the structure and specific metabolic activities of gastrointestinal microbiota, consequently impacting the host body. ${ }^{12,13}$ One of the functions of gut bacteria is to metabolize indigestible plant fibres and proteins to short-chain fatty acids (SCFAs) that are accessible to the intestinal cells. Butyrate and propionate are the most abundant SCFAs that regulate the intestinal physiology and immune function, followed by acetate, which is a substrate for lipogenesis and gluconeogenesis. ${ }^{14}$

The objective of the present study was to identify the nutritional and physiological effects of commercial protein preparations based on soy or whey proteins designed for sportsmen. It was hypothesized that diet supplementation with plant or animal preparations may result in diverse outcomes in the
Institute of Animal Reproduction and Food Research, Polish Academy of Sciences, Tuwima 10, 10-748 Olsztyn, Poland. E-mail: d.zlotkowska@pan.olsztyn.pl 
host body. To verify this hypothesis, a casein-based control diet and two experimental diets containing soy or whey proteins were supplied as the sole dietary protein source in growing rats. The host growth and physiology, and the gut microbiota balance and activity were then examined.

\section{Results and discussion}

\section{Characterization of whey and soy protein preparations}

The sport supplements $\mathrm{S}, \mathrm{W}$ and $\mathrm{C}$ were characterized by a high protein content of $85 \%, 86 \%, 89.7 \%$, respectively. Their basic composition and the amino acid composition are presented in Table 1.

The protein source in the diet directly affects the muscle protein synthesis (MPS) and skeletal muscle mass ${ }^{15}$. The essential amino acid composition (EAAs) and the protein digestibility corrected amino acid score refer to the ability of the protein source to increase MPS. Table 1 presents the amino acid composition in the studied casein, soy and whey preparations, according to the manufacturer's declaration. The AA composition of animal and plant proteins is varied. Many factors like plant variety, animal breed, climate, and fertilization in the case of plants and the cattle feeding system in the case of animals affect the AA composition, which are not the subject of the present study. According to Reeves ${ }^{16}$ a casein diet should be enriched with L-cysteine to protect animals from its deficiency. As Table 6 presents, diet $\mathrm{C}$ was used with methionine supplementation as advised. ${ }^{16}$

The content of protein fractions in the preparations was determined by SDS-PAGE (Fig. 1). The soy protein preparation (line S Fig. 1) revealed seven strong bands corresponding to

Table 1 Composition of protein preparations used in the in vivo experiment according to the producer information

\begin{tabular}{lccc}
\hline Preparation & Casein (C) & Soy (S) & Whey (W) \\
\hline Dry matter, \% & 92.58 & 87.52 & 91.70 \\
Protein, \% & 89.70 & 85 & 86 \\
Fat, \% & 0.38 & 3 & 0.3 \\
Carbohydrates of which sugars & & $1 \mathrm{~g}$ & 1 \\
& n.d. & $0.1 \mathrm{~g}$ & 1 \\
Amino acids & $\%$ of protein & & \\
Glycine & 1.93 & 4.14 & 1.71 \\
Alanine & 3.07 & 4.27 & 5.14 \\
Valine & 6.67 & 4.98 & 5.55 \\
Leucine & 9.70 & 8.17 & 10.79 \\
Isoleucine & 5.23 & 4.90 & 6.15 \\
Proline & 11.60 & 5.10 & 5.44 \\
Phenylalanine & 5.37 & 5.13 & 3.02 \\
Tryptophan & 1.30 & 1.28 & 1.21 \\
Serine & 5.87 & 5.17 & 4.34 \\
Threonine & 4.34 & 3.80 & 6.35 \\
Cysteine & 0.37 & 1.28 & 2.52 \\
Methionine & 3.04 & 1.35 & 2.22 \\
Arginine & 3.80 & 7.48 & 2.32 \\
Histidine & 3.12 & 2.56 & 1.71 \\
Lysine & 8.15 & 6.24 & 11.49 \\
Aspartic acid & 7.41 & 11.50 & 10.49 \\
Glutamic acid & 22.70 & 18.94 & 17.42 \\
Tyrosine & & 3.72 & 2.92 \\
& & &
\end{tabular}

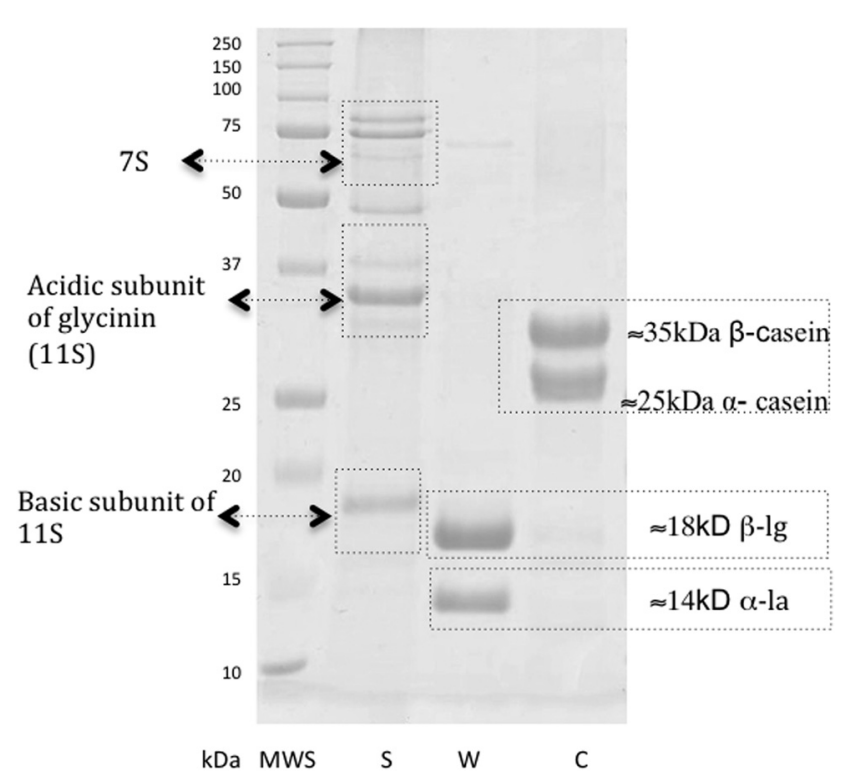

Fig. 1 Electrophoregram of protein SDS-PAGE: MWS - molecular weight standard (SIGMA), S - soy preparation; W - whey protein preparation; C - casein preparation.

proteins with molecular weights ranging from about 18 to $100 \mathrm{kDa}$, representing the major soy storage proteins. The bands of the molecular weight ranging from 18 to $20 \mathrm{kDa}$ correspond to the basic subunit of $11 \mathrm{~S}$ glycinin and the bands ranging from $35-40 \mathrm{kDa}$ correspond to the acidic subunit of glycinin (11S). The top three bands correspond to $7 \mathrm{~S}$ globulin. The whey protein preparation (line W Fig. 1) showed two strong bands with molecular weights of about $15 \mathrm{kDa}$ and $20 \mathrm{kDa}$, corresponding to $\alpha$-la and $\beta$-lg, respectively. The casein protein (line C Fig. 1) consisted of two fractions with molecular weights of $25 \mathrm{kDa}$ and $c a .35 \mathrm{kDa}$ corresponding to $\alpha$ and $\beta$ casein fractions, respectively.

The immunoreactivity of the tested soy and whey protein preparations was checked by competitive ELISA with antibodies against $\alpha$-la, $\beta$-lg, glycinin and lactoferrin (Fig. 2). Antibodies were produced and characterized by Wróblewska et al. (2009). ${ }^{17}$ Each sample was measured in duplicate; mean values $\pm \mathrm{SD}$ were used for ELISA curve preparation for standards and S and $\mathrm{W}$ samples. Cross reactions were calculated and presented in percentage $[\%] .{ }^{18,19}$

Whey is the liquid remaining after cheese, casein and yoghurt production, and presence of casein is natural. ${ }^{20}$ Preparation $\mathrm{W}$, as expected, showed high affinity to anti- $\alpha$-la and anti- $\beta$-lg antibodies (Fig. 2A and B). A strong reaction was also observed in the case of anti- $\alpha$-casein antibodies (data not shown), suggesting the presence of the casein fraction in preparation W, which probably remained after processing. ${ }^{20}$ A crossreaction of $\mathrm{W}$ proteins with anti-glycinin antibodies was found at a level of $20 \%$ (Fig. 2C), due to the presence of trace amounts of soy proteins as declared by the manufacturer. On the other hand, it was found that the serum of patients with milk allergy also reacts with soy proteins. ${ }^{21}$ This suggested 


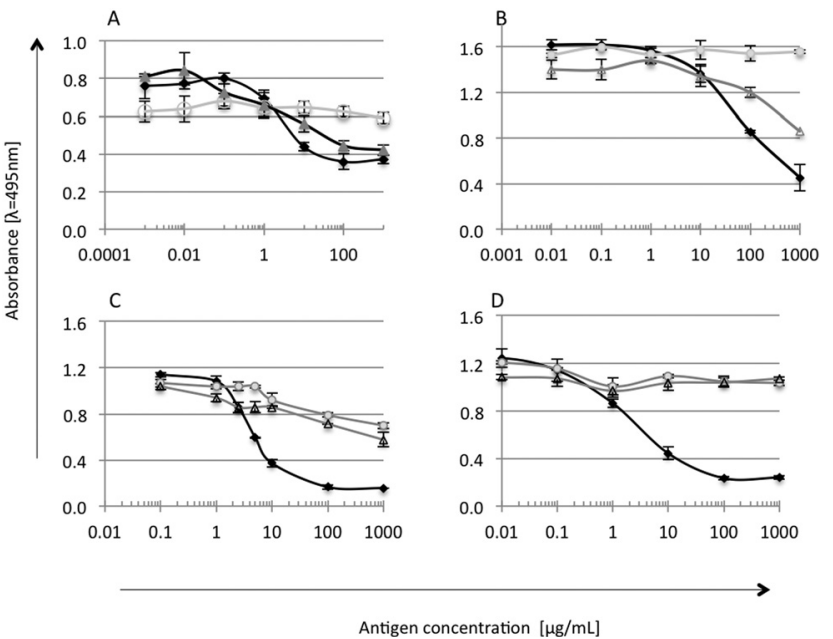

Fig. 2 Cross reactions of antibodies against: $A-\alpha$-la; $B-\beta$-lg; $C-$ glycinin; D - lactoferrin with $O$ soy preparation (S) and $\Delta$ whey preparation. - The antigen used to generate the antibody (standard curve).

some similarity in the IgE epitope sequence and a possible cross reaction of antibodies with two proteins of different species. ${ }^{22,23}$ Preparation $S$ did not show the presence of nonsoy proteins. A strong reaction with anti- $\beta$-glycinin antibodies (50\% cross reactivity level) confirmed that $\beta$-glycinin is one of the main proteins in the $\mathrm{S}$ preparation (Fig. 2C). Immunoblotting analysis of experimental preparations, with the serum of patients (data not shown), resulted in one slight band corresponding to $\beta$-glycinin reacting in the case of soy preparation. It confirms the possible allergenic properties of the soy preparation. ${ }^{24}$

Splenocytes from experimental rat groups were cultured and stimulated with $\beta$-lg and $\alpha$-casein (Fig. 3). The highest stimulation was observed in the cells obtained from the $\mathrm{C}$ group rats followed by the $\mathrm{W}$ group rats during stimulation with $\alpha$-casein.

The allergenicity of milk proteins has been well described. ${ }^{24-26}$ Rozenfeld et al. $(2002)^{27}$ reported that a large percentage of people with cow milk allergy also suffered from soy allergy, so the cross-reactivity between different proteins of

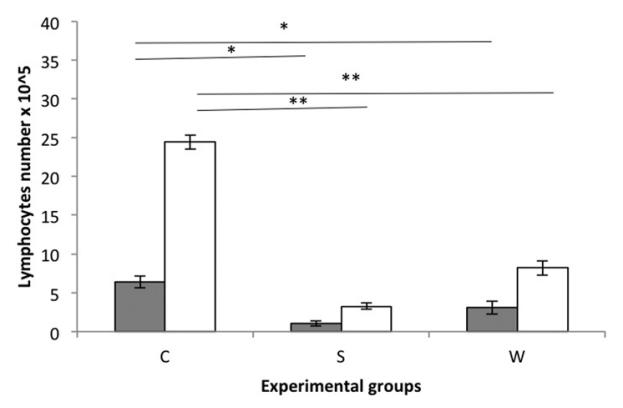

Fig. $348 \mathrm{~h}$ stimulation of splenocytes from the groups fed with casein (C), soy (S) and whey (W) protein preparations, with $\square \beta$-lg or $\square \alpha$-casein. Statistically significant differences * for $P<0.05$; ** for $P<0.001$. food may become a real problem for consumers who have an allergy to the analysed preparations. The present experiment determined the cross-reactivity between the whey preparation proteins and anti- $\beta$-glycinin antibodies to be about $20 \%$. However, in vitro stimulation of lymphocytes with $\alpha$-casein or $\beta$-lg did not enhance the proliferation of lymphocytes isolated from the $\mathrm{S}$ group in comparison with $\mathrm{W}$ and $\mathrm{C}$ rats. This is in agreement with the current opinion that soy is less allergenic than cow milk. ${ }^{28}$

\section{Protein and nitrogen balance}

Blood samples from the experimental groups of rats were checked for glucose, triglycerides, urea, AST and ASP levels. All contents were in reference standards provided by Charles River Laboratory. ${ }^{29}$ Rat growth parameters and diet intake for each protein source were analysed (Table 2).

The soy preparation had a significant decreasing effect on body weight gain $(P<0.05$ vs. $\mathrm{C}$ and $\mathrm{W})$ but not on diet intake. When compared to group $\mathrm{C}$, both fat and lean mass gains were significantly decreased by the soy protein preparation, whereas the whey preparation decreased only the lean mass gain $(P<0.05)$. Additionally, the group with $\mathrm{S}$ diet was associated with significantly lower lean and fat mass gain values relative to the $\mathrm{W}$ group. The diets based on soy and whey protein preparations significantly decreased the PER value compared with the $\mathrm{C}$ group $(P<0.05)$. Moreover, $\mathrm{S}$ treatment was associated with a significantly lower PER value relative to the $W$ group. These findings are in line with the FAO report ${ }^{30}$ concluding that generally plant-based proteins are characterized by lower digestibility compared to animal-based proteins. The dietary addition of soy proteins significantly increased faecal nitrogen $(\mathrm{N})$ excretion $(P<0.05 v s$. the other groups), and the lowest value of the apparent $\mathrm{N}$ digestibility index was noted in the $\mathrm{S}$ group (Table 2). Interestingly, the $\mathrm{W}$ group had a significantly lower quantity of $\mathrm{N}$ excreted in faeces compared to the $\mathrm{C}$ group, and the $\mathrm{N}$ digestibility rate was similar in the $\mathrm{C}$ and $\mathrm{W}$ groups. The quantity of $\mathrm{N}$ excreted in urine was significantly lower in the $\mathrm{C}$ (control) group than in those fed with experimental diets $(P<0.05)$, and in this regard the rates from group $S$ significantly exceeded the rats from group $W$. As a result of the above mentioned changes, the $\mathrm{N}$ utilization index, which considers the loss of $\mathrm{N}$ in both faeces and urine, was found to be the lowest in $\mathrm{S}$ treatment and the highest in the $\mathrm{C}$ group (in both cases, $P<0.05 v s$. other treatments). Exemplary animal and human studies provided evidence that poor or imbalanced dietary proteins increase nitrogen loss and limit protein synthesis, due to inefficient utilization of essential amino acids. ${ }^{31}$ Our study showed that the whey preparation as the sole protein source in diet was more useful compared to the soy preparation with respect to the efficiency of protein utilization for growth. There was no significant difference between the groups $\mathrm{C}$ and $\mathrm{W}$, in terms of body weight gain, even though the $\mathrm{W}$ group gained $10 \%$ less than the $\mathrm{C}$ group. In the group $\mathrm{S}$, the decrease in BW gain was high and amounted to $35 \%$, compared to the casein treatment. An et al. $(2014)^{32}$ did not find significant changes in the body weight gain during a 16-day 
Table 2 Body weight, diet intake, nitrogen excretion patterns, and body composition of rats fed with the experimental diets (mean \pm SD)

\begin{tabular}{|c|c|c|c|}
\hline & $\mathrm{C}$ & $\mathrm{S}$ & $\mathrm{W}$ \\
\hline Initial BW, $\mathrm{g}$ & $88.5 \pm 2.21$ & $88.4 \pm 3.37$ & $88.4 \pm 3.14$ \\
\hline Final BW, $\mathrm{g}$ & $232.4 \pm 14.31^{a}$ & $181.5 \pm 14.85^{b}$ & $217.9 \pm 13.15^{a}$ \\
\hline BW gain, g & $143.9 \pm 14.36^{a}$ & $93.1 \pm 15.44^{b}$ & $129.5 \pm 12.98^{a}$ \\
\hline Diet intake, $g$ & $446 \pm 26.30$ & $431 \pm 31.68$ & $445 \pm 18.10$ \\
\hline $\mathrm{PER}^{d}$ & $3.15 \pm 0.14^{a}$ & $2.06 \pm 0.26^{c}$ & $2.68 \pm 0.18^{b}$ \\
\hline \multicolumn{4}{|l|}{ Nitrogen $(\mathrm{N})$ balance test } \\
\hline $\mathrm{N}$ intake, $\mathrm{mg} 5 \mathrm{~d}^{-1}$ & $1345 \pm 103.52$ & $1302 \pm 830.15$ & $1312 \pm 119.64$ \\
\hline $\mathrm{N}$ in faeces, $\mathrm{mg}$ & $106 \pm 11.60^{b}$ & $132 \pm 11.60^{a}$ & $91.9 \pm 10.04^{c}$ \\
\hline $\mathrm{N}$ faecal, \%N intake & $7.89 \pm 0.86^{b}$ & $10.2 \pm 0.70^{a}$ & $7.02 \pm 0.68^{b}$ \\
\hline $\mathrm{N}$ in urine, $\mathrm{mg}$ & $299 \pm 60.53^{c}$ & $517 \pm 53.46^{a}$ & $439 \pm 43.84^{b}$ \\
\hline $\mathrm{N}$ urinary, $\% \mathrm{~N}$ intake & $22.2 \pm 3.79^{c}$ & $39.7 \pm 2.26^{a}$ & $33.7 \pm 4.67^{b}$ \\
\hline $\mathrm{N}$ digestibility, \% & $92.1 \pm 0.86^{a}$ & $89.8 \pm 0.70^{b}$ & $93.0 \pm 0.68^{a}$ \\
\hline $\mathrm{N}$ utilisation, \% & $69.9 \pm 3.28^{a}$ & $50.2 \pm 2.52^{c}$ & $59.3 \pm 4.64^{b}$ \\
\hline \multicolumn{4}{|l|}{ Body composition, $\mathrm{g}$} \\
\hline$\Delta$ MASS & $136.6 \pm 34.51^{a}$ & $89.9 \pm 30.26^{b}$ & $123.4 \pm 32.24^{a}$ \\
\hline$\Delta$ FAT & $50.4 \pm 20.65^{a}$ & $39.9 \pm 16.12^{b}$ & $47.2 \pm 18.67^{a}$ \\
\hline$\Delta$ LEAN & $43.2 \pm 19.80^{a}$ & $18.3 \pm 9.33^{c}$ & $35.8 \pm 21.50^{b}$ \\
\hline \multicolumn{4}{|l|}{ Body composition, \% } \\
\hline$\%$ FAT & $33.0 \pm 10.75$ & $35.0 \pm 11.31$ & $32.9 \pm 11.03$ \\
\hline$\%$ LEAN & $41.5 \pm 13.86$ & $39.0 \pm 9.05$ & $41.0 \pm 12.44$ \\
\hline
\end{tabular}

study but almost two times higher protein intake. ${ }^{23}$ The methionine level could affect body weight gain but in our study the lowest amount of methionine is in the $\mathrm{S}$ diet, $1.35 \%$ of proteins, which is about two times higher than that in the reference diet presented in a study by Zimmerman et al. (2003). ${ }^{33}$ The other reason could be just the properties of soy proteins. Mathai et al. $(2017)^{34}$ determined the standardised ileum digestibility (SID) of amino acids from whey and soy protein isolates. They confirmed that the SID of indispensable amino acids for soy amino acids was 1 to $4 \%$ lower than dairy proteins. These findings appear to explain the reason for the BW decrease in the experimental soy group. PDCAA is another parameter describing the dietary protein quality. Soy beans have a score of about 0.91 whereas for casein or whey the score is $1.00 .^{35}$ This is in agreement with our results regarding the differences in the ability to stimulate MPS (indirectly rat growth performance). Moore et al. (2009) ${ }^{36}$ found that the consumption of whey protein hydrolysates stimulated skeletal muscle protein synthesis to a greater extent than casein or soy. This is in agreement with the present study, wherein the anabolic effect of the whey protein preparation on skeletal muscles was apparently higher than the soy preparation, as evidenced by higher lean mass gain (group $\mathrm{W} v s$. group $\mathrm{S}$ ) (Table 2). This may be attributed to the varied leucine contents in the $\mathrm{S}$ and $\mathrm{W}$ preparations. Engelen et al. $(2007)^{37}$ demonstrated that supplementation of soy protein with some essential amino acids (leucine, isoleucine, and valine) was required to enhance its anabolic effect in the elderly and in patients. The evidence reported suggests that soy protein can exert beneficial effects on obesity and obesity-related disorders through the reduction of body weight, fat mass, and blood lipids. ${ }^{38}$ Our study appears to support these findings. The results obtained for rat body composition showed that body weight loss in the $\mathrm{S}$ group rats was related to the reduction of both fat and lean mass. However, the increased content of $\mathrm{N}$ found in the urine of S rats, and the equally high amount found in $\mathrm{W}$ rats compared to the $\mathrm{C}$ group show that both soy and whey preparation based diets can have different effects on the body. Increasing the soy diet intake probably reduced the body weight gain but future studies are needed to compare more physiological parameters presented in the study.

\section{Small and large intestine parameters and enzymatic activity}

Experimental treatment with the commercial whey protein supplement as the sole protein source had no significant effect on the small intestinal parameters tested, compared to the casein group (Table 3).

$\mathrm{S}$ treatment resulted in significantly higher relative mass of the intestine along with digesta and significantly lowered the dry matter concentration $(P<0.05 v s$. and $P<0.05$, vs. other treatments and $v s$. C, respectively). The activity of the small intestinal mucosal aminopeptidase was significantly lower in $\mathrm{S}$ rats when compared to the $\mathrm{C}$ group $(P<0.05)$. The low aminopeptidase activity correlates with the above described lower protein utilization during $\mathrm{S}$ feeding (Table 2). The lack of any negative effect on the jejunal disaccharidase activity in the tested groups indicates, however, the proper digestion and unhindered absorption of carbohydrates from the upper gastrointestinal tract during supplementation of the diet with both the tested preparations. Considering the colonic environment, the $\mathrm{W}$ treatment caused a significant increase in DM, in comparison with the $\mathrm{C}$ and $\mathrm{S}$ groups of rats $(P<0.05)$. Concurrently, the highest colonic activity of bacterial $\beta$-galactosidase was found in the $\mathrm{W}$ treatment $(P<0.05$ vs. other treatments). Reversely, the highest activities of bacterial $\alpha$-galactosidase and $\beta$-glucuronidase were found in the colonic 
Table 3 Gastrointestinal tract parameters in the rats fed with the experimental diets (mean \pm SD)

\begin{tabular}{|c|c|c|c|}
\hline & $\mathrm{C}^{d}$ & $\mathrm{~S}^{d}$ & $\mathrm{~W}^{d}$ \\
\hline \multicolumn{4}{|l|}{ Small intestine } \\
\hline Full mass, g $100 \mathrm{~g}$ per BW & $2.38 \pm 0.16^{\mathrm{b}}$ & $2.78 \pm 0.15^{\mathrm{a}}$ & $2.27 \pm 0.14^{\mathrm{b}}$ \\
\hline $\mathrm{DM}, \%$ & $19.0 \pm 1.39^{\mathrm{a}}$ & $17.4 \pm 0.93^{\mathrm{b}}$ & $18.9 \pm 0.99^{\mathrm{ab}}$ \\
\hline pH of digesta & $6.45 \pm 0.20$ & $6.61 \pm 0.22$ & $6.56 \pm 0.20$ \\
\hline \multicolumn{4}{|l|}{ Mucosal enzymes ${ }^{e}$} \\
\hline Sucrase & $4.43 \pm 0.64$ & $5.09 \pm 0.52$ & $4.89 \pm 0.48$ \\
\hline Maltase & $37.7 \pm 5.88$ & $34.0 \pm 5.12$ & $33.3 \pm 5.20$ \\
\hline Lactase & $1.55 \pm 0.38$ & $1.27 \pm 0.30$ & $1.49 \pm 0.51$ \\
\hline Aminopeptidase & $112 \pm 14.82^{\mathrm{a}}$ & $90.2 \pm 5.94^{\mathrm{b}}$ & $98.1 \pm 19.23^{\mathrm{ab}}$ \\
\hline \multicolumn{4}{|l|}{ Caecum } \\
\hline Tissue, g $100 \mathrm{~g}$ per BW & $0.175 \pm 0.02$ & $0.173 \pm 0.03$ & $0.167 \pm 0.02$ \\
\hline Digesta, g 100 g per BW & $0.702 \pm 0.08$ & $0.856 \pm 0.24$ & $0.719 \pm 0.14$ \\
\hline $\mathrm{DM}, \%$ & $25.9 \pm 1.39^{\mathrm{ab}}$ & $24.5 \pm 1.19^{\mathrm{b}}$ & $26.3 \pm 1.19^{\mathrm{a}}$ \\
\hline Ammonia, $\mathrm{mg} \mathrm{g}^{-1}$ of digesta & $0.203 \pm 0.02^{\mathrm{a}}$ & $0.111 \pm 0.01^{\mathrm{c}}$ & $0.162 \pm 0.03^{\mathrm{b}}$ \\
\hline pH of digesta & $7.19 \pm 0.18$ & $7.03 \pm 0.23$ & $7.05 \pm 0.16$ \\
\hline \multicolumn{4}{|l|}{ Bacterial enzyme activity ${ }^{f}$} \\
\hline$\alpha$-Glucosidase & $27.5 \pm 6.79^{\mathrm{b}}$ & $25.2 \pm 6.42^{\mathrm{b}}$ & $37.2 \pm 6.79^{\mathrm{a}}$ \\
\hline$\beta$-Glucosidase & $6.51 \pm 1.87$ & $6.96 \pm 0.80$ & $7.57 \pm 2.19$ \\
\hline$\alpha$-Galactosidase & $27.5 \pm 16.63$ & $38.4 \pm 8.37$ & $34.3 \pm 9.25$ \\
\hline$\beta$-Galactosidase & $63.1 \pm 17.45^{b}$ & $52.5 \pm 13.63^{\mathrm{b}}$ & $92.1 \pm 14.68^{\mathrm{a}}$ \\
\hline$\beta$-Glucuronidase & $57.9 \pm 19.97$ & $71.6 \pm 12.47$ & $67.6 \pm 15.22$ \\
\hline \multicolumn{4}{|l|}{ Colon } \\
\hline Tissue, g $100 \mathrm{~g}$ per BW & $0.391 \pm 0.06$ & $0.414 \pm 0.06$ & $0.399 \pm 0.05$ \\
\hline Digesta, g 100 g per BW & $0.378 \pm 0.09$ & $0.367 \pm 0.10$ & $0.355 \pm 0.09$ \\
\hline DM, \% & $35.8 \pm 1.39^{b}$ & $34.5 \pm 1.84^{b}$ & $39.3 \pm 1.73^{a}$ \\
\hline pH of digesta & $6.90 \pm 0.23$ & $7.02 \pm 0.20$ & $7.11 \pm 0.27$ \\
\hline \multicolumn{4}{|l|}{ Bacterial enzyme activity ${ }^{f}$} \\
\hline$\alpha$-Glucosidase & $18.2 \pm 2.97$ & $18.0 \pm 3.03$ & $19.9 \pm 1.30$ \\
\hline$\beta$-Glucosidase & $3.73 \pm 1.62$ & $5.00 \pm 1.49$ & $4.22 \pm 0.97$ \\
\hline$\alpha$-Galactosidase & $12.7 \pm 2.86^{b}$ & $21.3 \pm 6.08^{a}$ & $14.4 \pm 2.88^{b}$ \\
\hline$\beta$-Galactosidase & $47.3 \pm 10.44^{b}$ & $37.4 \pm 7.81^{b}$ & $70.9 \pm 5.54^{a}$ \\
\hline$\beta$-Glucuronidase & $32.0 \pm 6.87^{c}$ & $67.3 \pm 9.62^{a}$ & $43.7 \pm 9.62^{b}$ \\
\hline
\end{tabular}

digesta of rats fed with the $\mathrm{S}$ diet $(P<0.05)$, whereas the $\beta$-galactosidase activity was the lowest in this group $(P<0.05$ vs. W). An et al. (2014) ${ }^{32}$ stated that soy dietary proteins altered the intestinal environment, affecting fermentation by gut microbiota and the generation of putrefactive compounds.

\section{Caecal microbiota and its metabolic activity}

The caecum is the main site of bacterial fermentation processes in rats. ${ }^{35}$ Therefore, measurements of microbial metabolic activities, including enzymatic activity and SCFA concentrations, were determined in the caecal digesta. The 4-week administration of the $\mathrm{S}$ diet resulted in a significant decrease in caecal dry matter (DM) and ammonia concentration in comparison with the $\mathrm{C}$, and $\mathrm{C}$ and $\mathrm{W}$ diets, respectively $(P<0.05)$. The highest ammonia concentration in the caecum was observed for the $\mathrm{C}$ dietary treatment $(P<0.05 \mathrm{vs}$. S and $\mathrm{W})$. The balance between ammonia production and absorption by bacterial and intestinal cells is vital for maintaining the intestinal ammonia concentration, which has the potential to change the metabolism and morphology of the intestinal epithelium. ${ }^{40}$ In the intestine, ammonia is produced by proteolytic bacteria, such as Clostridium, Enterococci and Bacteroides, which are the major members of the normal hindgut microbiota. In the absence of sufficient energy from a carbohydrate source, gut microbiota can use undigested proteins as a source of energy, leading to the formation of ammonia and other putrefactive compounds. ${ }^{41}$ There was no enhancement in ammonia production as a result of experimental feeding in the study. The presented results are not consistent with the thesis provided by Clinton (1992) ${ }^{41}$ and suggest that the additional undigested protein entering the caecum is not sufficient to stimulate the bacterial proteolytic activity and ammonia production. A partial explanation for this may be derived from the observed ability of the soy preparation to inhibit the growth of caecal bacteria (Table 4). However, regarding the activity of the enzymes tested, we can also consider that some dietary level of easily fermented fibre appears to be a prerequisite to stimulate the bacterial production of glycolytic as well as proteolytic enzymes.

The dietary treatments had no effect on the Enterococcus spp. in the caecum. Counts of the remaining caecal bacteria were generally reduced in the rats fed with the soy protein preparation, whereas the whey preparation slightly enhanced some bacterial groups, compared to the control casein diet (Table 4).

Marked differences were only observed for the S diet, which lowered sulphite reducing bacteria in comparison with the $\mathrm{W}$ 
Table 4 Bacterial counts in wet caecal contents (log CFU per gram \pm SD)

\begin{tabular}{|c|c|c|c|}
\hline & $\mathrm{C}$ & $\mathrm{S}$ & $\mathrm{W}$ \\
\hline Total anaerobic bacteria & $10.15 \pm 0.28^{b}$ & $9.67 \pm 0.48^{a}$ & $10.14 \pm 0.34^{b}$ \\
\hline Bifidobacterium spp. & $9.28 \pm 1.16$ & $8.91 \pm 0.71$ & $9.55 \pm 0.85$ \\
\hline Sulphite reducing bacteria & $5.12 \pm 1.30^{a b}$ & $4.4 \pm 1.27^{b}$ & $6.05 \pm 1.10^{a}$ \\
\hline Lactobacillus spp. & $9.34 \pm 0.51$ & $9.18 \pm 0.48$ & $8.98 \pm 0.59$ \\
\hline Enterobacteriaceae & $4.91 \pm 1.05$ & $4.31 \pm 1.07$ & $5.35 \pm 0.82$ \\
\hline Enterococcus spp. & $6.92 \pm 0.88$ & $6.99 \pm 0.59$ & $7.10 \pm 0.59$ \\
\hline
\end{tabular}

${ }^{\mathrm{a}, \mathrm{b}, \mathrm{c}}$ Mean values within a row with dissimilar superscript letters were significantly different (ANOVA $P<0.05$ ).

group $(P<0.05)$. In the $\mathrm{W}$ treatment, the highest activities of bacterial $\alpha$-glucosidase and $\beta$-galactosidase were found (Table $3, P<0.05 v s$. other treatments), which correlate with the observed enhanced bacterial growth in the $\mathrm{W}$ rats. The enhancement of health-promoting bacteria such as Bifidobacteria is beneficial, nevertheless, the most visible effect (up and down regulation) was observed in the case of sulphite reducing bacteria. These microorganisms include, among others, potentially pathogenic species such as C. difficile and C. perfringens, and therefore belong to opportunistic microbiota, which in the healthy gut is in balance with other intestinal microbes. Their slightly enhanced growth observed in the W group, however, seems not to counteract with the physiology. These results correlate with the protein utilization and the body weight gain of the tested groups (Table 2). In all probability, sulphite reducing Clostridia and some other anaerobic bacteria may have found good growth conditions in the $\mathrm{C}$ and $\mathrm{W}$ rats due to their high proteolytic activity, whereas additional factors may have affected their growth in the S group. Soy is an abundant source of proteins that have been recognized for their nutritional value and bioactive properties. Vasconcellos et al. $(2014)^{42}$ stated that hydrolysates of glycinin and $\beta$-conglycinin (the major components of soy protein isolates, accounting for approximately $85 \%$ of total protein in soy) represent an excellent source of antimicrobial and antioxidant compounds, with great potential for use as therapeutic agents. Similarly, Roubos-van den Hil et al. $(2010)^{43}$ described the strong antibacterial activity of soy tempe extract (proteinaceous nature) against Bacillus cereus cells and spores, and this antibacterial activity was only released during soy fermentation. Thus, the observed reduction of bacterial counts upon soy treatment may result from the antimicrobial activity of the preparation.

Despite some microbiological dissimilarities described above, the total caecal concentration of SCFA was not affected by any of the dietary treatments, mainly due to the high concentrations of acetic and butyric acids (Table 5).

The $\mathrm{W}$ group surpassed the other treatments only in the concentration of iso-butyric acid $(P<0.05)$. However, the dietary incorporation of $\mathrm{W}$ proteins into the diet caused a significant increase in the ratio of propionic acid to total SCFA $(P<0.05$ vs. other treatments). The $\mathrm{S}$ group was characterized by a significant decrease in the caecal concentrations of propionic, iso-butyric, iso-valeric, and valeric acids, compared to the $\mathrm{C}$
Table 5 Concentration and profile of SCFA in the caecal digesta $($ mean $\pm S D)$

\begin{tabular}{lccc}
\hline & $\mathrm{C}$ & $\mathrm{S}$ & $\mathrm{W}$ \\
\hline SCFA, $\boldsymbol{\mu \text { mol g }}$ per digesta & & \\
Acetic acid & $55.3 \pm 9.02$ & $50.3 \pm 7.41$ & $53.3 \pm 6.79$ \\
Propionic acid & $9.26 \pm 1.92^{a}$ & $6.97 \pm 1.22^{b}$ & $10.2 \pm 1.39^{a}$ \\
Iso-butyric acid & $0.88 \pm 0.17^{b}$ & $0.59 \pm 0.06^{c}$ & $1.08 \pm 0.08^{a}$ \\
Butyric acid & $9.86 \pm 2.52$ & $8.75 \pm 2.18$ & $9.26 \pm 2.15$ \\
Iso-valeric acid & $0.87 \pm 0.14^{a}$ & $0.59 \pm 0.08^{b}$ & $0.82 \pm 0.20^{a}$ \\
Valeric acid & $1.58 \pm 0.37^{a}$ & $1.08 \pm 0.14^{b}$ & $1.44 \pm 0.28^{a}$ \\
Total PSCFA & $3.33 \pm 0.54^{a}$ & $2.25 \pm 0.17^{b}$ & $3.33 \pm 0.31^{a}$ \\
Total SCFA & $77.7 \pm 12.53$ & $68.3 \pm 10.07$ & $76.1 \pm 9.39$ \\
Profile, \% SCFA of total & & \\
Acetic acid & $71.1 \pm 2.46^{a b}$ & $73.7 \pm 2.09^{a}$ & $70.0 \pm 2.40^{b}$ \\
Propionic acid & $11.6 \pm 0.88^{b}$ & $10.2 \pm 0.99^{c}$ & $13.5 \pm 1.05^{a}$ \\
Butyric acid & $12.7 \pm 2.77$ & $12.7 \pm 1.87$ & $12.1 \pm 1.70$ \\
& & \\
a,b,c Mean values within a row with dissimilar superscript letters were \\
significantly different (ANOVA $P<0.05$ ). ${ }^{d}$ PSCFA - putrefactive short- \\
chain fatty acids (the sum of iso-butyric, iso-valeric, and valeric acids).
\end{tabular}

and $\mathrm{W}$ animals. The profile analysis of three major fatty acids (acetic, propionic, and butyric) revealed that dietary treatment with the $\mathrm{S}$ preparation was characterized by a significantly lower ratio of propionic acid to total SCFA $(P<0.05 v s$. C and $\mathrm{W})$ and a significantly higher ratio of acetic acid to total SCFA, when compared to the control. The changed metabolic profile of the gut microbiota and the observed decrease of bacterial growth in the $\mathrm{S}$ group can be a result of the antibacterial activity of some components of soy preparation. The main propionate producers are strict anaerobes belonging to the phyla Firmicutes (Negativicutes class, families Veillonellaceae and Lachnospiraceae, Lachnospiraceae) and Bacteroidetes. ${ }^{44}$ Whether soy proteins act directly on propionate producing bacteria or on other bacteria via disturbing cross-feeding routes needs further investigation using advanced molecular techniques.

\section{Experimental}

\section{Characteristics of protein preparations}

SDS-PAGE. SDS-PAGE was performed according to the Laemmli method ${ }^{45}$ using a Mini PROTEAN 3 Cell (Bio-Rad). The proteins were separated in a $12.5 \%$ gel run at $30 \mathrm{~V}$ for $30 \mathrm{~min}$ and at $100 \mathrm{~V}$ for $120 \mathrm{~min}$. A molecular weight marker ranging from 10 to $250 \mathrm{kDa}$ (161-0373, Bio-Rad) was used. The 
gels were stained with $0.2 \%$ Coomassie Brilliant Blue R-250 solution (17 524, Serva).

Western blotting. The proteins separated by SDS-PAGE were transferred onto a nitrocellulose membrane using a Mini Trans-Blot apparatus (Bio-Rad) with tris-glycine buffer in methanol, pH 8.3 (192 mmol L ${ }^{-1}$ glycine, $25 \mathrm{mmol} \mathrm{L}^{-1}$ Tris, and $20 \% \mathrm{v} / \mathrm{v}$ methanol). The membrane was then incubated overnight at $4{ }^{\circ} \mathrm{C}$ with primary antibodies (pooled sera from patients with known soy/milk allergy). After three washes in PBS-Tween $0.5 \%$, the blot was processed for antigen detection by incubating for $1 \mathrm{~h}$ with the corresponding secondary HRPlabelled anti-human IgE (A9667, Sigma). After three further washes in PBS-Tween $0.5 \%$, the allergenic fractions were visualized by their reaction with the substrate (4-chloro-1naphthol, C6788, Sigma) that produced navy blue bands.

Human serum. The human sera used for western blot analysis were collected from five adult patients with diagnosed food allergies. Sera were assayed to have a total IgE over 100 $\mathrm{kU} \mathrm{L}^{-1}$ (ImmunoCAP, Phadia UniCAP-system, Sweden), and specific IgE to cow-milk proteins, hen egg white, soy, dust and tree and grass pollen (Allergy Profile Pediatrics test, DP 37121601 E, EUROIMMUN, Poland).

The study complied with all institutional and national guidelines, the protocol was approved by the Bioethical Committee at the Faculty of Medical Science of the University of Warmia and Mazury in Olsztyn (\#2/2010), and all participants provided written informed consent.

Competitive ELISA. The immunoreactivity of protein preparations was examined by competitive ELISA which was performed according to standard laboratory protocols. Rabbit polyclonal specific antibodies (generated in-house) against $\alpha$-lactalbumin $(\alpha$-la), $\beta$-lactoglobulin $(\beta$-lg), $\alpha$-casein, $\beta$-casein, $\kappa$-casein, lactoferrin, soy $\beta$-conglycinin, and glycinin were used. ${ }^{17}$ Pure antigens and secondary horseradish peroxidaselabelled antibodies were purchased from Sigma. The binding percentage of cross-reaction (CR\%) of the specific antibodies with the supplement proteins was determined as follows: ${ }^{46}$

$$
\mathrm{CR}[\%]=C_{\text {stan }} / C_{\text {sample }} \times 100
$$

where CR[\%] - cross-reaction in $\% ; C_{\text {stan }}$ - the concentration of the standard needed for $50 \%$ absorbance reduction; $C_{\text {sample }}{ }^{-}$ the concentration of the sample needed for $50 \%$ absorbance reduction.

\section{In vivo experiment}

Male Wistar rats aged $30 \mathrm{~d}(n=24)$ and weighing $88.4 \mathrm{~g} \pm 1.012$ were randomly divided into three groups of eight animals each. All animals were housed individually in metabolic cages with free access to water and the experimental diets (Table 6).

The selection of animals and their maintenance over the 28 $\mathrm{d}$ experiment followed the common regulations. The environment was controlled with a $12 \mathrm{~h}$ light-dark cycle, a temperature of $21 \pm 1^{\circ} \mathrm{C}$, a relative humidity of $50 \pm 5 \%$, and twenty air changes per h. In experimental groups three isonitrogenous diets were used: group $\mathrm{C}$ - a control diet based on casein
Table 6 Composition of the experimental diets

\begin{tabular}{llll}
\hline Diet & $\mathbf{C}[\% \mathrm{w} / \mathrm{w}]$ & $\mathbf{S}[\% \mathrm{w} / \mathrm{w}]$ & $\mathbf{W}[\% \mathrm{w} / \mathrm{w}]$ \\
\hline Casein & 11.15 & - & - \\
Soy preparation & - & 11.94 & - \\
Whey preparation & - & - & 11.82 \\
DL-Methionine & 0.15 & - & - \\
Cellulose & 5.00 & 5.00 & 7.00 \\
Soybean oil & 8.00 & 7.64 & 3.50 \\
Mineral mix & 3.50 & 3.50 & 1.00 \\
Vitamin mix & 1.00 & 1.00 & 70.71 \\
Maize starch & 71.20 & 70.92 & 10.84 \\
Content analysed & 10.21 & 10.45 & \\
Protein, \% & & &
\end{tabular}

preparation supplemented with $0.15 \%$ DL-methionine; ${ }^{47}$ group $\mathrm{S}$ - a diet based on soy and group $\mathrm{W}$ - a diet based on whey protein preparations as the sole protein source. Diets S and $\mathrm{W}$ were not supplemented with DL-metionine, which was approved by the Local Animal Commission. The experiment premise was to make them the most comparable to the diet consumed by the person, thereby creating a new trend in diet based on one source of protein. Diets were prepared in the powder form as a mixture of all ingredients and stored at $4{ }^{\circ} \mathrm{C}$. Rats were fed ad libitum once a day. The control diet was a modification of the AIN-93G diet recommended by the American Institute of Nutrition; ${ }^{16}$ the dietary protein level in all treatments was reduced to $c a$. $10.5 \%$ of dry matter (DM), a dose enabling the measurement of the protein utilization rate to determine animal growth. Owing to the balanced experiment, every diet, faecal, and urine samples were analysed in duplicate for crude protein. ${ }^{39,48}$ Chemical analyses showed that the diets were properly prepared: the crude protein contents of the $\mathrm{C}, \mathrm{S}$ and $\mathrm{W}$ diets were $10.21,10.45$, and $10.84 \%$ of DM, respectively.

During the study, the rats were subjected to a nitrogen $(\mathrm{N})$ balance test from the $10^{\text {th }}$ day until the $15^{\text {th }}$ day of feeding experiment. During those $5-\mathrm{d}$, faeces and urine were thoroughly collected from all rats that were housed in balanced cages (Tecniplast Spa, Buguggiate, Italy). The experimental groups were monitored for body weight gain (BW, recorded at the beginning and the end of the experiment) and diet intake (daily monitoring), which enabled the calculation of the protein efficiency ratio (PER). ${ }^{49}$ Furthermore, at the beginning and at the end of the nutritional experiment, the body composition of the rats (lean and mass) was analysed and calculated by time-domain nuclear magnetic resonance using a Minispec LF 90II (Bruker, Karlsruhe, Germany).

The animal protocol used in this study was approved by the Local Committee for the Ethical Treatment of Experimental Animals of Warmia-Mazury University, Olsztyn, Poland (bioethical committee permission no 56/2012) and the study was performed in accordance with the EU Directive 2010/63/ EU for animal experiments.

\section{Sample collection and analysis}

Upon termination of the experiment, the rats were anaesthetized with sodium pentobarbital according to the recommen- 
dations for euthanasia of experimental animals. After laparotomy, blood samples were collected from the portal vein. Serum was prepared by solidification and low-speed centrifugation (350g, $\left.10 \mathrm{~min}, 4^{\circ} \mathrm{C}\right)$. Samples were kept frozen at $-70^{\circ} \mathrm{C}$ until assayed.

The small intestine, caecum, and colon were removed and weighed. Immediately after euthanasia (ca. $10 \mathrm{~min}$ ), the $\mathrm{pH}$ values of the contents of the small intestine, caecum, and colon were measured ( $\mathrm{pH}$ meter model 301, Hanna Instruments, Vila do Conde, Portugal).

\section{Biochemical analyses of blood}

After experiment termination, blood was collected and glucose, triacylglycerol, urea, ALT, and AST were analysed on the Horiba Medical Pentra C200 clinical chemistry benchtop analyser (HORIBA ABX SAS, USA). As a reference levels published by Charles River Laboratories for male rats were used.

\section{Lymphocyte stimulation with $\beta$-lactoglobulin and $\alpha$-casein}

After experiment termination, the rats' spleens (SPL) were removed and lymphocytes were isolated according to the standard protocol. ${ }^{43}$ Cell suspensions of $1 \times 10^{6}$ per $\mathrm{mL}$ were cultured in RPMI 1640 (Sigma) medium supplemented with 10\% FBS, 1\% penicillin-streptomycin solution, 1\% non-essential amino acids, $1 \%$ sodium pyruvate, and 1\% HEPES. After $12 \mathrm{~h}$ of incubation for stabilization, $\beta$-lg (Sigma, Poland) or $\alpha$-casein (Sigma, Poland) was added at a concentration of $1 \mathrm{mg} \mathrm{mL} \mathrm{m}^{-1}$. Lymphocytes were cultured in triplicate at $37{ }^{\circ} \mathrm{C}$ in $5 \% \mathrm{CO}_{2}$ for the next $48 \mathrm{~h} .{ }^{50}$ Before and after stimulation, live lymphocytes were counted using the TC20® Cell Counter (Bio-Rad).

\section{Ammonia and short-chain fatty acids analyses}

In fresh caecal digesta, the ammonia $\left(\mathrm{NH}_{3}\right)$ content was determined by micro-diffusion analysis in Conway's dishes, and SCFAs were determined by gas chromatography (Shimadzu GC-2010, Kyoto, Japan) equipped with a capillary column (SGE BP21, $30 \mathrm{~m} \times 0.53 \mathrm{~mm}$, SGE Europe Ltd, Kiln Farm Milton Keynes, UK) as previously described. ${ }^{51}$

\section{Enzymatic activity in the small and large intestine}

Disaccharidase activity (expressed as $\mu \mathrm{mol}$ of glucose released per min per $g$ of protein) in the jejunal mucosa was analysed according to the method described by Messer and Dahlqvist $(1966)^{52}$ with modifications. ${ }^{53}$ Aminopeptidase-N (E.C. 3.4.11.2) was assayed using L-alanine- $p$-nitroanilide as a substrate. ${ }^{54}$ Absorbance was measured at $384 \mathrm{~nm}$, and the activity was determined using a $p$-nitroaniline standard curve.

The activity of selected bacterial enzymes ( $\alpha$ - and $\beta$-glucosidase, $\alpha$ - and $\beta$-galactosidase, and $\beta$-glucuronidase) released into the caecum was measured from the rate of $p$ - or $o$-nitrophenol released from their nitrophenylglucosides, according to the standard methods. ${ }^{55}$

\section{Analysis of caecal microbiota}

Caecal samples collected directly from each rat were weighed, snap-frozen in liquid nitrogen, placed in Anaerocult A mini bags (Merck), and stored at $-80{ }^{\circ} \mathrm{C}$ until analysis. For microbiological evaluation, the frozen samples were directly transferred to an anaerobic workstation (Whitley MG500 anaerobic workstation, DW Scientific) under $80 \% \mathrm{~N}_{2}, 10 \% \mathrm{CO}_{2}$ and $10 \%$ $\mathrm{H}_{2}$. After defrosting and sample homogenization, appropriate serial decimal dilutions were made in the Brain Heart Infusion broth (BHI, Difco), and aliquots were plated on agar media in duplicate. The total number of anaerobes was enumerated on Schaedler's agar enriched with vitamin K1 and 5\% sheep blood (Difco, BD), Bifidobacterium was counted on modified Garche's agar, ${ }^{56}$ and sulphite reducing bacteria were counted on Differential Reinforced Clostridial Agar (Difco, BD). In all cases, plates were incubated under anaerobic conditions at $37^{\circ} \mathrm{C}$ for $72 \mathrm{~h}$. For the evaluation of aerobic and facultative anaerobic bacteria, aliquots were plated on specific agar media under aerobic conditions and incubated at $37^{\circ} \mathrm{C}$ for $48 \mathrm{~h}$. Enterobacteriaceae was enumerated on MacConkey's agar with crystal violet (Difco, BD). Lactobacilli were enumerated on MRS agar (Merck) plates overlaid with a second layer of medium. Enterococci were enumerated on Kanamycin Esculin Azide Agar (KEA, Merck) and yeast was enumerated on Sabouraud's Dextrose Agar with chloramphenicol (BBL, BD). The identity of representative colonies recovered from the selective media was confirmed by conventional microbiological tests including the colony appearance (examined under a stereoscopic microscope SZX9, Olympus), cellular morphology (examined by phase contrast microscopy, Microphot FXA, Nikon), Gram staining, and biochemical patterns using API systems (BioMerieux). Genus affiliation of the grown Bifidobacteria was also checked based on the presence of Bifidobacteria-specific fructose-6-phosphoketolase (F6PPK-EC 4.1.2.22) ${ }^{57}$ Bacterial counts were expressed as log of the number of colony forming units (CFU) per gram wet-weight of faeces.

\section{Statistical analyses}

Results were analysed statistically using one-way analysis of variance (ANOVA) at a significance level of $P<0.05$. When significant treatment effects were found in the ANOVA, post-hoc comparisons were performed using the Tukey's range test. ${ }^{58}$ Data were expressed as mean values (for physiological measurements, $n=8$ for each group) and standard deviation (SD). Calculations were performed with STATISTICA ${ }^{\circledR} 10.0$ (StatSoft Inc., Krakow, Poland).

\section{Conclusions}

The results obtained in this study showed the diversified potential of the tested protein preparations in modulating the physiology, gastrointestinal digestion, and growth performance of the rats. Both whey and soy protein preparations still showed allergenic potential. Casein and whey protein diets yielded a significantly higher total body weight of rats than the soy diet, with similar diet intake. Rats fed with casein or whey preparations possessed twice as much lean body mass compared to the ones fed with soy proteins. Consequently, differ- 
ences in the PER and nitrogen balance were observed. Definitely preparations based on cow milk proteins can be used in the diets targeted for athletes for rapid muscle mass gain.

The use of different sources of proteins in the diet significantly affected the small intestinal digestive enzymes and the intestinal microbiota balance and activity. The potential of these products to modify the gut microbiota and their ultimate use in dietetics require further research.

\section{Conflicts of interest}

There are no conflicts to declare.

\section{Acknowledgements}

The article processing charge was covered by the KNOW Consortium: "Healthy Animal - Safe Food" (Ministry of Sciences and Higher Education; Dec: 05-1/KNOW2/2015).

\section{Notes and references}

1 K. A. Escobar and T. A. McLain, Strength Cond. J., 2015, 37(3), 1-13.

2 A. Khanam, R. K. Chikkegowda and B. Swamylingappa, J. Food Sci. Technol., 2013, 50(2), 309-316.

3 D. Rankin and A. Darragh. Dietary protein in an endurance exercise recovery beverage - what is the value of whey?, in The 4th International Whey Conference, Chicago, IL, ed. American Dairy products Institute, 2005, pp. 13-24.

4 B. Pennings, Y. Boirie, J. M. G. Senden, A. P. Gijsen, H. Kuipers and L. J. C. van Loon, Am. J. Clin. Nutr., 2011, 93(5), 997-1005.

5 P. C. Pereira, A. F. Vicente and A. S. Cabrita, FASEB J., 2008, 22(1 Supp.), 877.9.

6 WHO, FAO UEC. PROTEIN AND AMINO ACID REQUIREMENTS IN Human NUTRITION, World Health Organization technical report series, Geneva, 2007, vol. 935.

7 A. L. Kau, P. P. Ahern, N. W. Griffin, A. L. Goodman and J. I. Gordon, Nature, 2011, 474(7351), 327-336.

8 P. Lagiou, S. Sandin, M. Lof, D. Trichopoulos, H.-O. Adami and E. Weiderpass, Br. Med. J., 2012, 344(3), e4026-e4026.

9 S. T. Jeor, B. V. Howard, T. E. Prewitt, V. Bovee, T. Bazzarre, R. H. Eckel, et al., Circulation, 2001, 104(15), 1869-1874.

10 L. M. Nilsson, A. Winkvist, I. Johansson, B. Lindahl, G. Hallmans, P. Lenner, et al., Nutr. J., 2013, 12(1), 58.

11 A. Fiocchi, H. Sampson, S. Bahna and G. Lack, Food Allergy, in WOA White Book of Allergy, World Allergy Organisation, Milwaukee, WI, 2011, pp. 47-53.

12 D. Graf, R. Di Cagno, F. Fåk, H. J. Flint, M. Nyman, M. Saarela, et al., Microb. Ecol. Health Dis., 2015, 26, 261-264.
13 L. H. Markiewicz, J. Honke, M. Haros, D. Świątecka and B. Wróblewska, J. Appl. Microbiol., 2013, 115(1), 247259.

14 J. R. Marchesi, D. H. Adams, F. Fava, G. Hermes, G. M. Hirschfield, G. Hold, et al., Gut, 2015, 65(2), 1-10.

15 R. R. Wolfe, J. Nutr., 2002, 132(10), 3219S-3224S.

16 P. G. Reeves, Exp. Biol., 1997, 127(5 Suppl.), 838-841.

17 B. Wróblewska, P. Kołakowski, K. Pawlikowska, A. Troszyńska and A. Kaliszewska, Food Hydrocolloids, 2009, 23, 2434-2445.

18 J. Hed, Phadia, 2009, 16-17.

19 A. Vojdani and I. Tarash, Food Nutr. Sci., 2013, 4, 20-32.

20 G. Bylund, Dairy Processing Handbook, Tetra Pak Processing Systems, 2015, vol. G3, pp. 480.

21 M. Masilamani, S. Commins and W. Shreffler, Immunol. Allergy Clin. North Am., 2012, 32(1), 11-33.

22 A. M. Candreva, P. L. Smaldini, R. Curciarello, A. Cauerhff, C. A. Fossati, G. H. Docena, et al., Allergy, Asthma Immunol. Res., 2015, 7(1), 60-68.

23 H. Matsuo, T. Yokooji and T. Taogoshi, Allergol. Int., 2015, 64, 332-343.

24 H. Hochwallner, U. Schulmeister, I. Swoboda, S. Spitzauer and R. Valenta, Methods, 2014, 66(1), 22-33.

25 B. Wroblewska and L. Jedrychowski, Milk Allergens, in Chemical and Biological Properties of Food Allergens, ed. L. Jedrychowski and H. J. Wichers, CRC Press/Taylor \& Francis, Boca Raton, FL, 2010, pp. 193-212.

26 B. Wróblewska and A. Kaliszewska, Czech J. Food Sci., 2012, 30(3), 211-219.

27 P. Rozenfeld, G. H. Docena, M. C. Añón and C. A. Fossati, Clin. Exp. Immunol., 2002, 130(1), 49-58.

28 J. D. Kattan, R. R. Cocco and K. M. Järvinen, Pediatr. Clin. North Am., 2011, 58(2), 407-426.

29 M. Giknis and C. Clifford. Clinical Laboratory Parameters for Crl:WI (HAN), 2008.

30 S. Gilani, D. Tomé, P. Moughan and B. Burlingame. PROTEIN AND AMINO ACID REQUIREMENTS IN HUMAN NUTRITION Report of a Joint WHO/FAO/UNU Expert Consultation, 2002.

31 E. Ha and M. B. Zemel, J. Nutr. Biochem., 2003, 14, 251258.

32 C. An, T. Kuda, T. Yazaki, H. Takahashi and B. Kimura, Appl. Microbiol. Biotechnol., 2014, 98, 2779-2787.

33 J. A. Zimmerman, V. Malloy, R. Krajcik and N. Orentreich, Exp. Gerontol., 2003, 38, 47-52.

34 J. Mathai, Y. Liu and H. Stein, Br. J. Nutr., 2017, 117(04), 490-499.

35 S. Van Vliet, N. A. Burd and L. J. C. Van Loon, J. Nutr. Crit. Rev., 2015, 145, 1981-1991.

36 D. R. Moore, M. J. Robinson, J. L. Fry, J. E. Tang, E. I. Glover, S. B. Wilkinson, et al., Am. J. Clin. Nutr., 2009, 89, 161-168.

37 M. P. Engelen, E. P. Rutten, C. L. De Castro, E. F. Wouters, A. M. Schols and N. E. Deutz, Am. J. Clin. Nutr., 2007, 85(2), 431-439. 
38 M. T. Velasquez and S. J. Bhathena, Int. J. Med. Sci., 2007, 4(2), 72-82.

39 J. Juskiewicz, Z. Zdunczyk, K. Bohdziewicz and M. Baranowska, Int. Dairy J., 2012, 26(2), 155-161.

40 J. Juskiewicz, Z. Zdunczyk and S. Frejnagel, Arch. Anim. Nutr., 2007, 61(3), 201-210.

41 S. Clinton, Dietary protein and carcinogenesis, in Nutrition, toxicity, and cancer, ed. I. R. Rowland, CRC Press, Boca Raton, FL, 1991, pp. 455-479.

42 F. C. S. Vasconcellos, A. L. Woiciechowski, V. T. Soccol, D. Mantovani and C. R. Soccol, Int. J. Curr. Microbiol. Appl. Sci., 2014, 3(8), 144-157.

43 P. J. Roubos-van den Hil, E. Dalmas, M. J. R. Nout and T. Abee, J. Appl. Microbiol., 2010, 109(1), 137-145.

44 D. Ríos-Covián, P. Ruas-Madiedo, A. Margolles, M. Gueimonde, C. G. de los Reyes-Gavilán and N. Salazar, Front. Microbiol., 2016, 7, 185.

45 F. He, Laemmli-SDS-PAGE, Bio-protocol, 2011, Bio101, e80, DOI: $10.21769 /$ BioProtoc. 80 .

46 J. Ruprich and V. Ostrý, Cent. Eur. J. Public Health, 2008, 16(1), 34-37.

47 NFIA. Vol. 3 Amino Acids, Special Purpose, Miscellaneous products, Method: Supplemented Amino Acids (methionine and lysine), in Laboratory Methods Compendium, West Des Moines, Iowa, 1991, pp. 71-72.
48 AOAC. Official Methods of Analysis of AOAC International. Association of Official Analysis Chemists International, 2006, CD-ROM.

49 F. Steinke. Protein Efficiency Ratio Pitfalls and Causes of Variability: A Review. Vol. 54, Cereal Chemistry, 1976, pp. 949-957.

50 D. Mierzejewska, P. Mitrowska, B. Rudnicka, E. Kubicka and H. Kostyra, Food Chem., 2008, 111(1), 127-131.

51 M. Wroblewska, J. Juskiewicz and W. Wiczkowski, Lipids Health Dis., 2011, 10, 178.

52 M. Messer and A. Dahlqvist, Anal. Biochem., 1966, 14(3), 376-392.

53 A. Jurgoński, J. Juśkiewicz and Z. Zduńczyk, Nutrition, 2013, 29(6), 898-902.

54 S. Maroux, D. Louvard and J. Barath, BBA - Enzymol., 1973, 321(1), 282-295.

55 J. Juskiewicz, Z. Zduńczyk and M. Wróblewska, Czech J. Anim. Sci., 2005, 50(6), 273-280.

56 J. Rasic, Bull. Int. Dairy Fed., 1990, 252, 24-31.

57 V. Scardovi. Genus Bifidobacterium Orla-Jensen, in Bergey's Manual of Systematic Bacteriology, ed. P. H. A. Sneath, N. S. Mair, M. E. Sharpe and J. G. Holt, Williams \& Wilkins, Baltimor, 1986, pp. 1418-1434.

58 V. Bewick, L. Cheek and J. Ball, One-way analysis of variance, Crit. Care, 2004, 8(2), 130-136. 